\title{
PEMETAAN PROFIL ANTROPOMETRI, DAN BIOKIMIA DARAH SEBAGAI UPAYA PREVENTIF TERHADAP PENYAKIT TIDAK MENULAR DI KELURAHAN TOMANG JAKARTA BARAT
}

\author{
Alexander Halim Santoso ${ }^{1}$, Triyana Sari $^{2}$, Shirly Gunawan ${ }^{3}$ \\ ${ }^{1}$ Bagian Ilmu Gizi, Fakultas Kedokteran, Universitas Tarumanagara Jakarta \\ Email:alexanders@fk.untar.ac.id \\ ${ }^{2}$ Bagian Biologi, Fakultas Kedokteran, Universitas Tarumanagara Jakarta \\ Email: triyanas@fk.untar.ac.id \\ ${ }^{3}$ Bagian Farmakologi Klinik, Fakultas Kedokteran, Universitas Tarumanagara \\ Email: shirlyg@fk.untar.ac.id
}

\begin{abstract}
Increasing the welfare of the community has an impact on lifestyle changes such as low physical activity, high carbohidrate and low diet. Along with these conditions, the incidence of non-communicable diseases (PTM / NonCommunicable Diseases / NCD) also increases. PTM includes cardiovascular disease, diabetes mellitus, lung disease and cancer. WHO reports that each year PTM causes 35 million deaths worldwide, and many of these deaths occur in low-to-middle income economies. Obesity is one of the risk factors for PTM. Many residents of Tomang village are known to suffer from diabetes. Based on the above conditions, the Faculty of Medicine intends to carry out anthropometric and biochemical profiles to get a picture of the nutritional status and PTM in Tomang village. The invitation was distributed by cadres from Tomang Urban Village. On the day of implementation, participants registered and then filled out the questionnaire. Furthermore, participants were directed to anthropometric examination, and continued with biochemical examination. This dedication activity involved Tarumanagara University Faculty of Medicine students. From eighty-three residents, only $10.8 \%$ of residents had high blood pressure (hypertension), high blood sugar (GDS) (> $200 \mathrm{mg} / \mathrm{dL}$ ) 4.8\%, high cholesterol (> $200 \mathrm{mg} / \mathrm{dL}$ ) 16 , 9\%, and high uric acid (male> $7 \mathrm{mg} / \mathrm{dL}$; female $>6 \mathrm{mg} / \mathrm{dL}$ ) 25.3\%. Based on the calculation of the Body Mass Index (BMI), it was found that more than sixty percent of the population had more nutritional status to fat. Continuous efforts are needed in the form of outreach to continue to increase community awareness and knowledge of PTM.
\end{abstract}

Keywords: Non-communicable diseases; Tomang Village; hypertension; when blood sugar; body mass index

\begin{abstract}
ABSTRAK
Peningkatan kesejahteraan masyarakat berdampak terhadap perubahan gaya hidup seperti aktifitas fisik yang rendah, pola makan tinggi energi dan rendah serta. Seiring dengan keadaan tersebut, insiden penyakit tidak menular (PTM/Non-Communicable Diseases/NCD) ikut meningkat. PTM mencakup penyakit kardiovaskuler, diabetes melitus, penyakit paru dan kanker. WHO melaporkan setiap tahunnya PTM menyebabkan 35 juta kematian di seluruh dunia, dan kematian ini banyak terjadi di negara berpendapatan ekonomi rendah hingga sedang. Obesitas merupakan salah satu faktor resiko terjadinya PTM. Banyak warga kelurahan Tomang diketahui menderita Diabetes. Berdasarkan kondisi diatas, Fakultas Kedokteran hendak melaksanakan pemeriksaan antropometri dan profil biokimia untuk mendapatkan gambaran mengenai status gizi dan PTM di kelurahan Tomang. Penyebaran undangan dilakukan oleh para kader dari Kelurahan Tomang. Pada hari pelaksanaan, peserta melakukan registrasi dan kemudian mengisi kuesioner. Selanjutnya peserta diarahkan untuk pemeriksaan antropometri, dan dilanjutkan dengan pemeriksaan biokimia. Kegiatan pengabdian ini melibatkan mahasiswa Fakultas Kedokteran Universitas Tarumanagara. Dari delapan puluh tiga warga, didapatkan hanya 10,8\% warga yang tekanan darahnya tinggi (hipertensi), gula darah sewaktu (GDS) tinggi (>200 mg/dL) 4,8\%, kolesterol tinggi (>200 mg/dL) 16,9\%, dan asam urat tinggi (laki-laki >7 mg/dL; perempuan >6 mg/dL) 25,3\%. Berdasarkan perhitungan Indeks Massa Tubuh (IMT), didapatkan lebih dari enampuluh persen warga memiliki status gizi lebih hingga gemuk. Diperlukan upaya berkelanjutan dalam bentuk penyuluhan untuk tetap meningkatkan kewaspadaan dan pengetahun masyarakat akan PTM.
\end{abstract}

Kata kunci: Penyakit Tidak Menular; Kelurahan Tomang; hipertensi; gula darah sewaktu; indeks massa tubuh 


\section{PENDAHULUAN}

Peningkatan kesejahteraan masyarakat berdampak terhadap perubahan gaya hidup seperti aktifitas rendah, pola makan tinggi energi dan rendah serat. Seiring dengan keadaan tersebut, insiden penyakit tidak menular (PTM) ikut meningkat.(Alwan \& MacLean, 2009) Penyakit-penyakit tidak menular (NCD) seperti penyakit kardiovaskular, stroke, diabetes melitus, merupakan penyakitpenyakit utama yang menyebabkan kematian pada manusia. Organisasi Kesehatan Dunia (WHO) melaporkan bahwa setiap tahunnya PTM menyebabkan kematian 35 juta penduduk dunia, di mana hampir tiga perempat kematian terjadi di negara-negara berpendapatan ekonomi rendah hingga sedang.(Alwan \& MacLean, 2009; Gowshall \& Taylor-Robinson, 2018) Data WHO lainnya menyebutkan penyakit kardiovaskular setiap tahunnya menyebabkan kematian sebesar 17,5 juta penduduk, sedangkan diabetes melitus menyebabkan 1,5 juta kematian tiap tahunnya. PTM biasanya timbul pada kelompok penduduk berusia tua, namun data menunjukkan bahwa dari 16 juta kematian yang disebabkan oleh PTM, terjadi pada usia di bawah 70 tahun. Selain faktor-faktor diatas, sejumlah faktor metabolik juga berperan terhadap peningkatan risiko PTM, seperti meningkatnya tekanan darah, kelebihan berat badan, obesitas, dan meningkatnya kadar gula darah.(World Health Organization, n.d.)

Obesitas merupakan salah satu faktor resiko terjadinya Penyakit Tidak Menular (PTM). Berdasarkan data dari WHO tahun 2008, angka kejadian obesitas pada usia dewasa di Indonesia sebesar $9,4 \%$ dengan pembagian pada pria mencapai $2,5 \%$ dan pada wanita $6,9 \%$. Survei sebelumnya pada tahun 2000, persentase penduduk Indonesia yang obesitas hanya 4,7\% ( $\pm 9,8$ juta jiwa) dan ternyata dalam waktu 8 tahun prevalensi obesitas di Indonesia meningkat hingga dua kali lipat. Hasil Riset Kesehatan Dasar (Riskesdas) tahun 2013 menunjukkan bahwa prevalensi obesitas nasional pada orang dewasa berusia lebih dari 18 tahun di Indonesia adalah 15,5\%.(Badan Penelitian dan Pengembangan Kesehatan Kementerian Kesehatan RI, 2013) Pada laki-laki dewasa, prevalensi obesitas mengalami peningkatan sebesar 11,9\% dibandingkan dengan hasil Riskesdas 2010 dan pada perempuan dewasa, prevalensi obesitas juga meningkat sebesar 15,2\% dibandingkan dengan hasil Riskesdas 2010. Prevalensi obesitas di Daerah Khusus Ibukota (DKI) Jakarta lebih tinggi dibandingkan angka prevalensi nasional.

Obesitas dapat menyebabkan berbagai dampak penyakit yang dapat mengancam kesehatan manusia. Obesitas dikaitkan dengan peningkatan PTM seperti dislipidemia, hipertensi, penyakit jantung dan pembuluh darah, diabetes, dan lain lain. Obesitas juga menurunkan produktifitas kerja. Rata-rata prevalensi kelebihan berat badan relatif tinggi pada usia 35-59 tahun pada laki-laki maupun perempuan.

Kelurahan Tomang dengan luas wilayah $1,88 \mathrm{~km}^{2}$, terdiri atas 16 rukun warga (RW), 174 rukun tetangga (RT) dan 8841 kepala keluarga (KK). Kelurahan ini berbatasan langsung dengan kelurahan Cideng, kelurahan Jatipulo, kelurahan Tanjung Duren Selatan dan kelurahan Grogol. Kelurahan Tomang memiliki jumlah penduduk sebesar 36,220 jiwa (18,591 laki-laki dan 17,639 perempuan). Berdasarkan hasil wawancara dan data dari kepala puskesmas Tomang didapatkan banyaknya warga kelurahan Tomang yang menderita diabetes. Pada data tersebut didapatkan diabetes merupakan penyakit yang menempati urutan ke 8 dari 10 penyakit tersering. Selain itu ditemukan pula kurangnya pengetahuan masyarakat tentang diabetes melitus, pencegahannya serta pengaturan pola hidup yang sehat.

\section{METODE PELAKSANAAN}

Berdasarkan permasalahan yang dihadapi masyarakat Kelurahan Tomang Jakarta Barat maka Fakultas Kedokteran Universitas Tarumanagara mengadakan kegiatan Pengabdian Masyarakat (Abdimas) berupa pemeriksaan antropometri, gula darah, lipid dan asam urat di kelurahan Tomang 
Jakarta Barat. Kegiatan Abdimas ini merupakan salah satu perwujudan tridharma perguruan tinggi di bidang Pengabdian dan Pelayanan kepada Masyarakat (P2M) yang memerlukan peran serta dosen, karyawan dan mahasiswa. Kegiatan ini ditujukan kepada warga Kelurahan Tomang Jakarta Barat, khususnya yang berusia sekitar 30-50 tahun, yang beresiko terhadap penyakitpenyakit tidak menular (PTM) seperti diabetes mellitus, dyslipidemia, hiperuresemia. Diharapkan melalui kegiatan ini, masyarakat dapat mengetahui status kesehatan dan dapat melakukan upayaupaya lanjut untuk mencegah insiden PTM dan komplikasinya.

Luaran yang hendak dicapai pada kegiatan Abdimas ini adalah memberikan pelayanan pemeriksaan status gizi berdasarkan antropometri (berat badan, tinggi badan) dan pemeriksaan gula darah, lipid, dan asam urat pada masyarakat di kelurahan Tomang Jakarta Barat dan untuk mengetahui prevalensi gizi lebih/obesitas, penyakit tidak menular (PTM) seperti diabetes, dislipidemia dan radang sendi (gout) pada masyarakat di kelurahan Tomang Jakarta Barat.

Pemaparan kegiatan dilakukan di kantor Kelurahan Tomang dan mendapat persetujuan dari Kepala Lurah Kelurahan Tomang. Selanjutnya dilakukan pendataan terhadap warga melalui kader-kader di Kelurahan. Warga yang terdaftar dibagikan kupon peserta yang diminta untuk dibawa pada hari kegiatan pengabdian.

Kegiatan dilaksanakan pada hari Minggu, 27 Januari 2019, bertempat di RPTRA Kelurahan Tomang, Jakarta Barat, jam 08.00-14.00 WIB. Pada hari pelaksanaan, peserta yang hadir diminta untuk melakukan registrasi ulang, dan dilakukan pendataan ulang. Peserta kemudian diminta untuk duduk dan menunggu panggilan dari panitia untuk pemeriksaan antropometri (berat badan dan tinggi badan), tekanan darah, dan pemeriksaan darah.

Pengukuran berat badan dilakukan dengan menggunakan timbangan pegas. Timbangan diletakkan diatas permukaan yang rata. Peserta yang akan diukur berat badannya diminta untuk melepaskan perlengkapan yang melekat di badan seperti ban pinggang, jam tangan, telepon genggam, dan alas kaki. Peserta diminta untuk naik ke atas timbangan, berdiri tegak dengan kedua lengan lurus disamping badan, dan memandang lurus ke depan. Pengukuran dilakukan dua kali dan diambil nilai rata-ratanya.

Pengukuran tinggi badan dilakukan dengan menggunakan alat microtoise yang digantungkan pada permukaan dinding yang rata. Peserta yang akan diukur tinggi badannya diminta untuk melepaskan alas kaki, sanggul kepala, berdiri tegak menempel pada dinding dan memandang lurus ke depan. Pengukur memastikan bahwa bagian belakang kepala, bahu, bokong, betis, dan tumit menempel pada dinding. Pengukuran dilakukan sebanyak dua kali dan diambil nilai rata-rata nya.(CDC, 2007; Gibson, 2005)

Pengukuran tekanan darah dilakukan dengan menggunakan tensimeter air raksa (spyghmomanometer). Sebelum pengukuran alat dipastikan bekerja dengan baik. Peserta yang akan diukur diminta untuk duduk tenang, melipat lengan baju. Lengan yang akan dipasang manset harus rileks, tersangga dan bebas dari tekanan pakaian. Lengan diposisikan setinggi jantung, dan manset dipasang mengelilingi lengan atas. Pengukur meraba denyut arteri brakialis atau arteri radialis. Setelah teraba, stetoskop diletakkan di atas titik dimana denyut arteri teraba. Alat dipompa dan kembangkan manset sampai pulsasi tidak teraba, naikkan hingga $30 \mathrm{mmHg}$, kemudian manset dikempiskan secara perlahan-lahan. Bunyi yang terdengar pertama kali setelah manset dikempiskan merupakan tekanan sistolik dan bunyi yang terakhir terdengar adalah tekanan diastolik.(CDC, 2007; Gibson, 2005) 
Pemeriksaan kadar gula darah, lemak darah, dan asam urat dilakukan dengan menggunakan alat glucometer dan POC lipid analyser. Sebelum pemeriksaan, alat dipastikan berfungsi dengan baik. Jari tangan yang akan digunakan dibersihkan secara asepsis dan antisepsis dengan kapas alkohol dan dibiarkan mongering. Tes strip dimasukkan ke dalam glucometer, kemudian cocokkan angka yang tertera pada layar dengan angka yang tertera pada tabung tes strip. Letakkan alat penusuk pada ujung jari kemudian tekan tombolnya untuk memperoleh darah. Setelah darah keluar, buang tetesan pertama dengan kapas, kemudian pada tetesan kedua dekatkan dengan tes strip pada glucometer dan biarkan darah mengalir ke dalam tes strip dalam jumlah yang cukup. Setelah darah didapatkan, ujung jari ditekan dengan kapas kering. Tunggu 5-10 detik hingga alat menunjukkan hasil pemeriksaan.(Bickley \& Szilagyi, 2007). Alur kegiatan dapat dilihar pada Gambar 1.

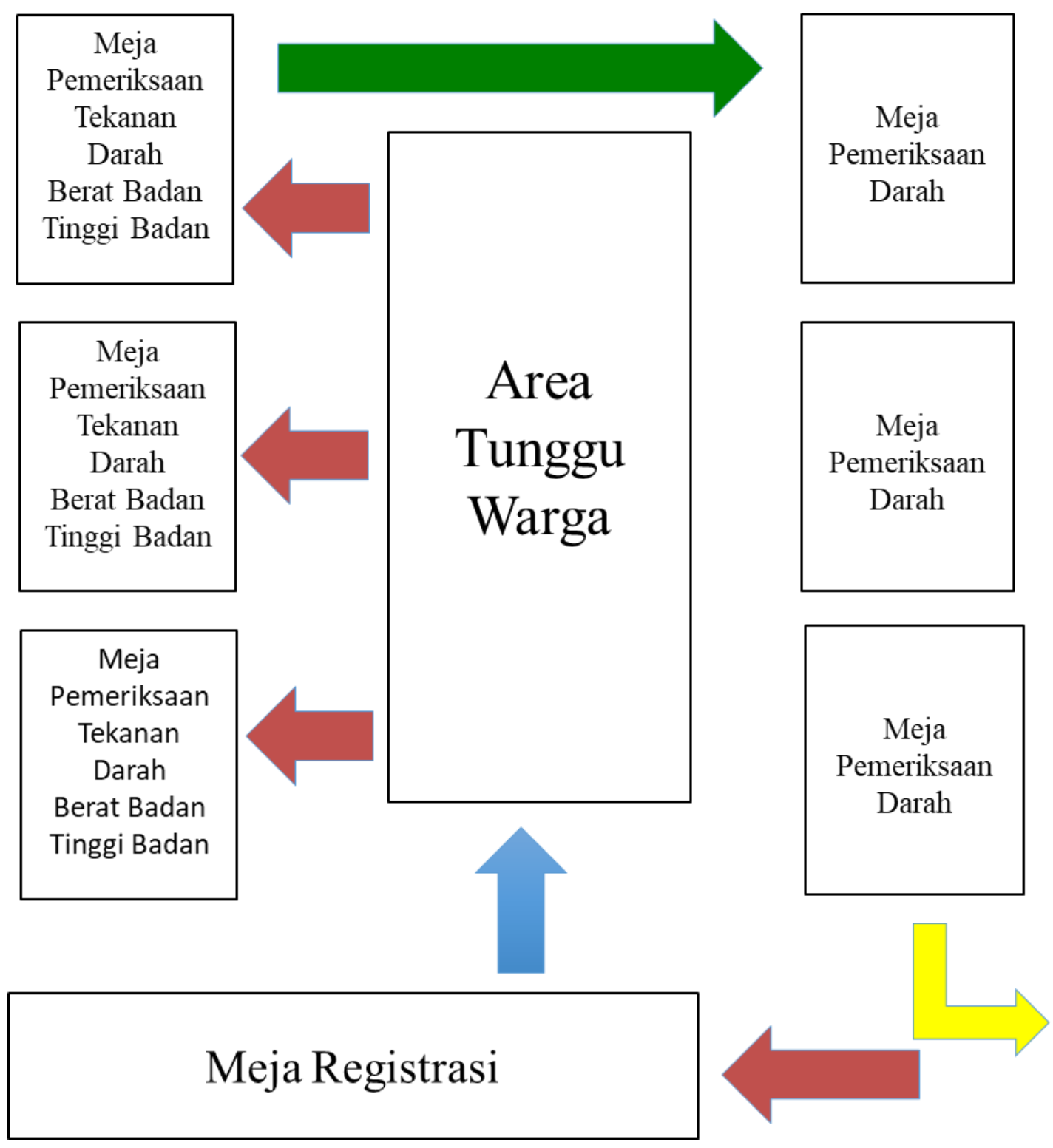

Gambar 1. Alur Kegiatan 


\section{HASIL YANG DIDAPATKAN}

Kegiatan diikuti oleh 83 warga. Pada hari pelaksanaan kegiatan, warga kelurahan Tomang diketahui baru mengalamai musibah kebakaran yang menimpa beberapa rukun warga (RW). Dokumentasi kegiatan dapat dilihat pada Gambar 2 sampai dengan Gambar 4.

Pada kegiatan ini, lebih dari separuh peserta yang menghadiri kegiatan berjenis kelamin perempuan $(81,9 \%)$. Lebih dari tujuh puluh lima persen warga yang hadir berusia di atas 40 tahun; sebanyak $27,7 \%$ diantaranya sudah berusia lebih dari 60 tahun. Diketahui usia termuda warga yang menghadiri kegiatan adalah 14 tahun, dan usia tertua warga yang menghadiri adalah 78 tahun. Penyakit tidak menular dapat terjadi pada semua golongan usia, baik di negara maju maupun negara berkembang. Data dari WHO menunjukkan bahwa 15 juta kematian akibat PTM terjadi pada rentang usia 30 sampai 69 tahun. Lebih dari 85\% kematian tersebut terjadi di negara berpendapatan rendah hingga menengah.(WHO, 2014) Didapatkan 44,6\% warga yang memiliki anak lebih dari 2 orang. Sebanyak $65,1 \%$ warga diketahui menamatkan pendidikan hingga sekolah menegah atas.

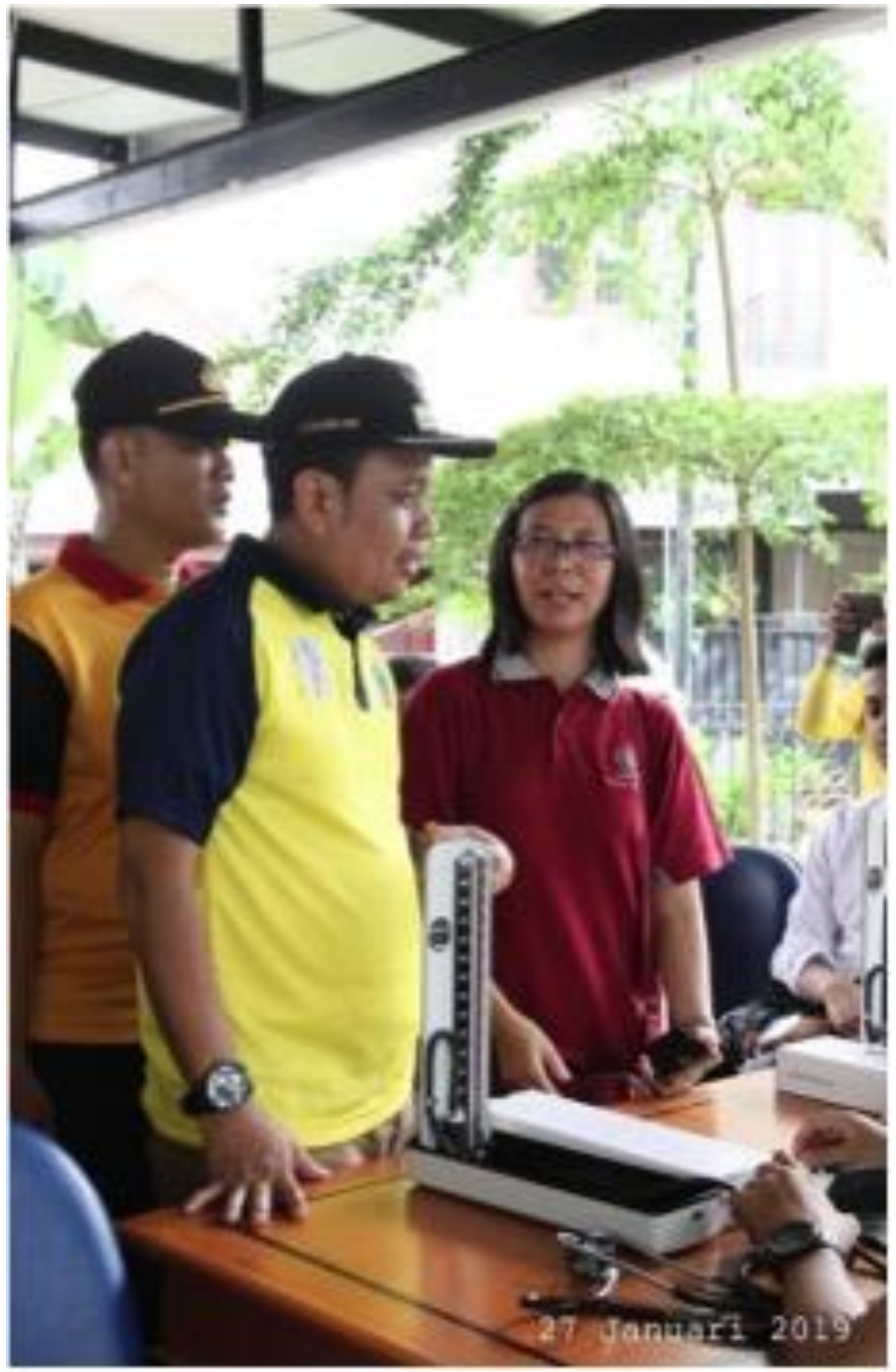

Gambar 2. Dokumentasi Kegiatan (1) 

Upaya Preventif terhadap Penyakit Tidak Menular di Kelurahan Tomang Jakarta Barat

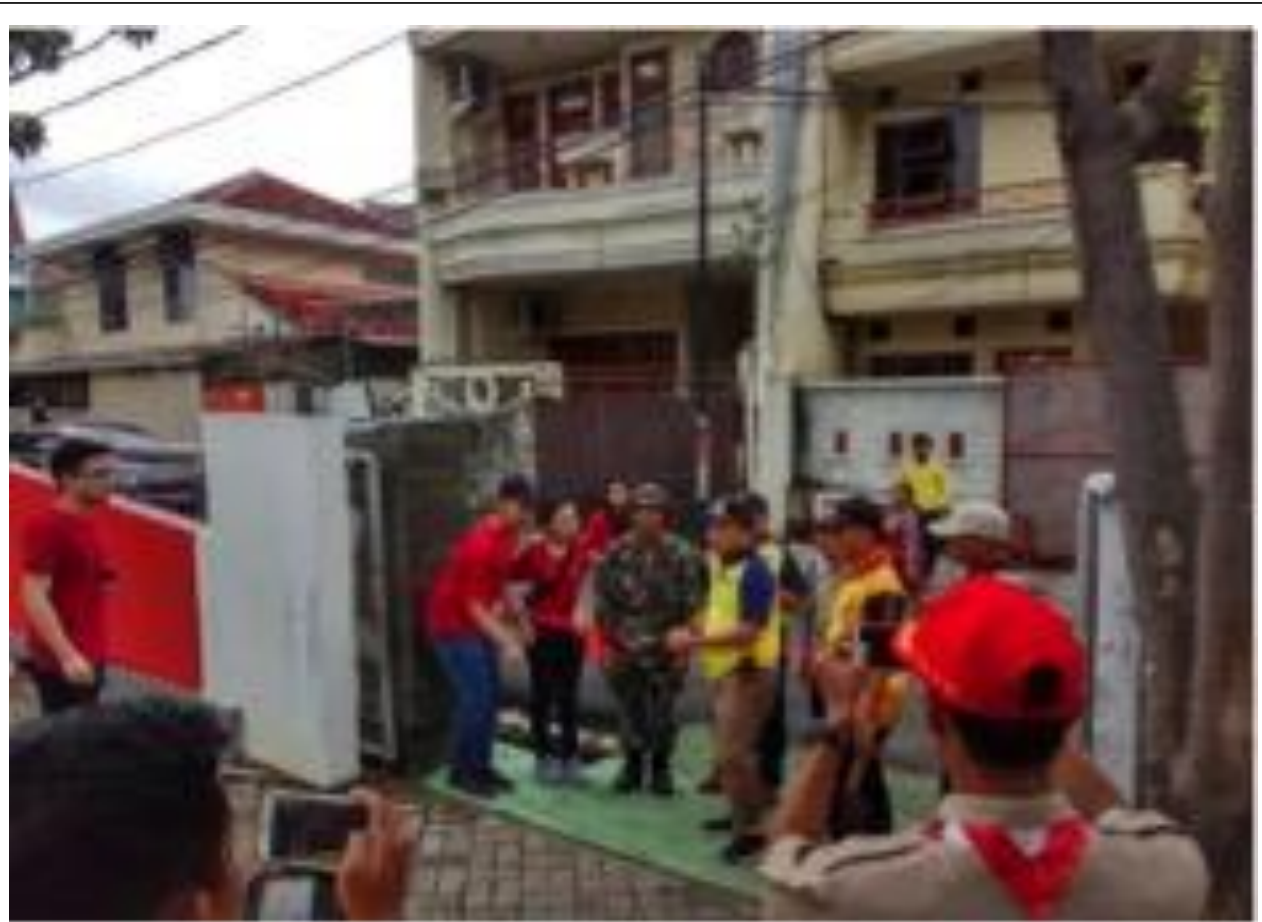

Gambar 3. Dokumentasi Kegiatan (2)

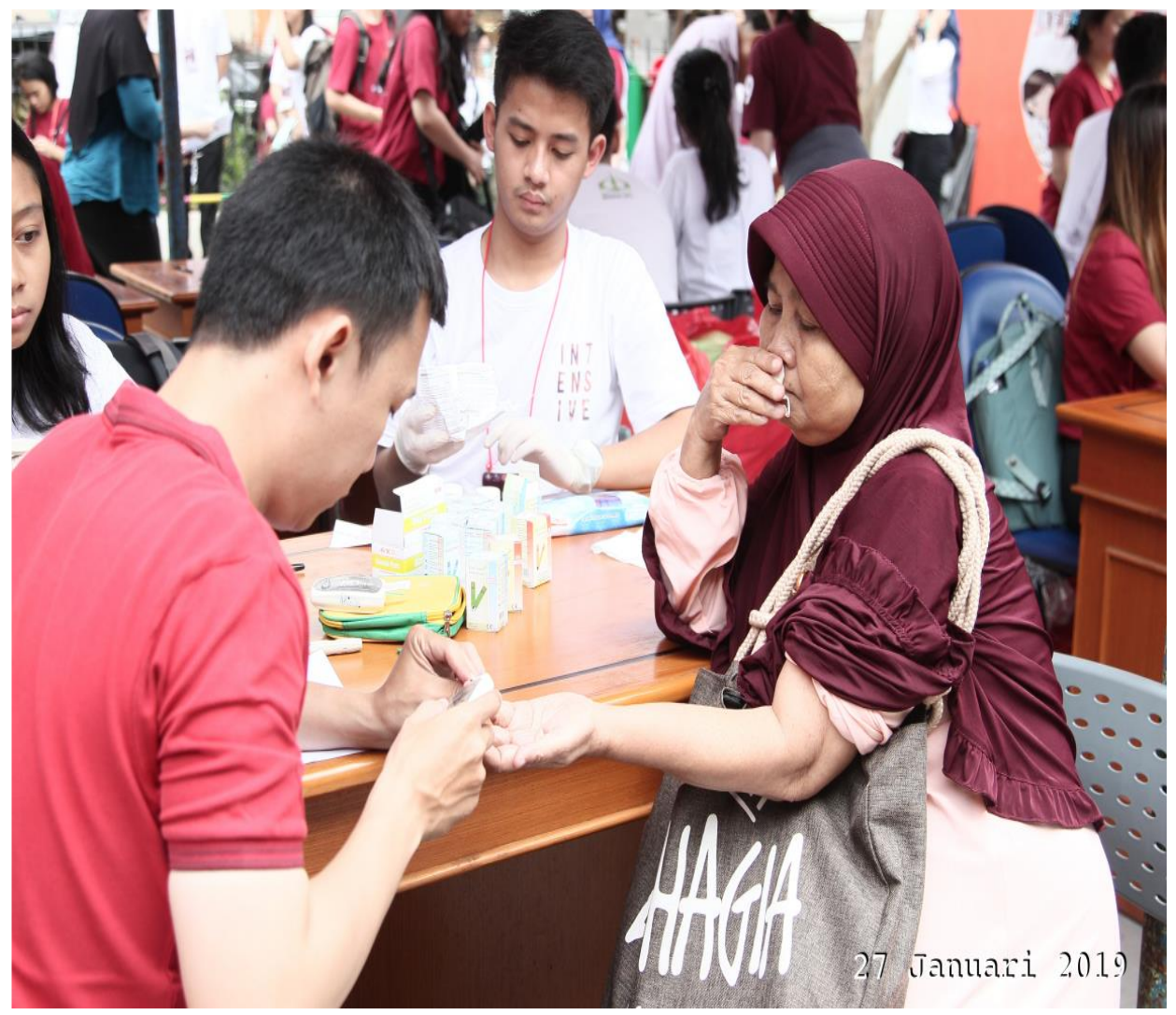

Gambar 4. Dokumentasi Kegiatan (3) 


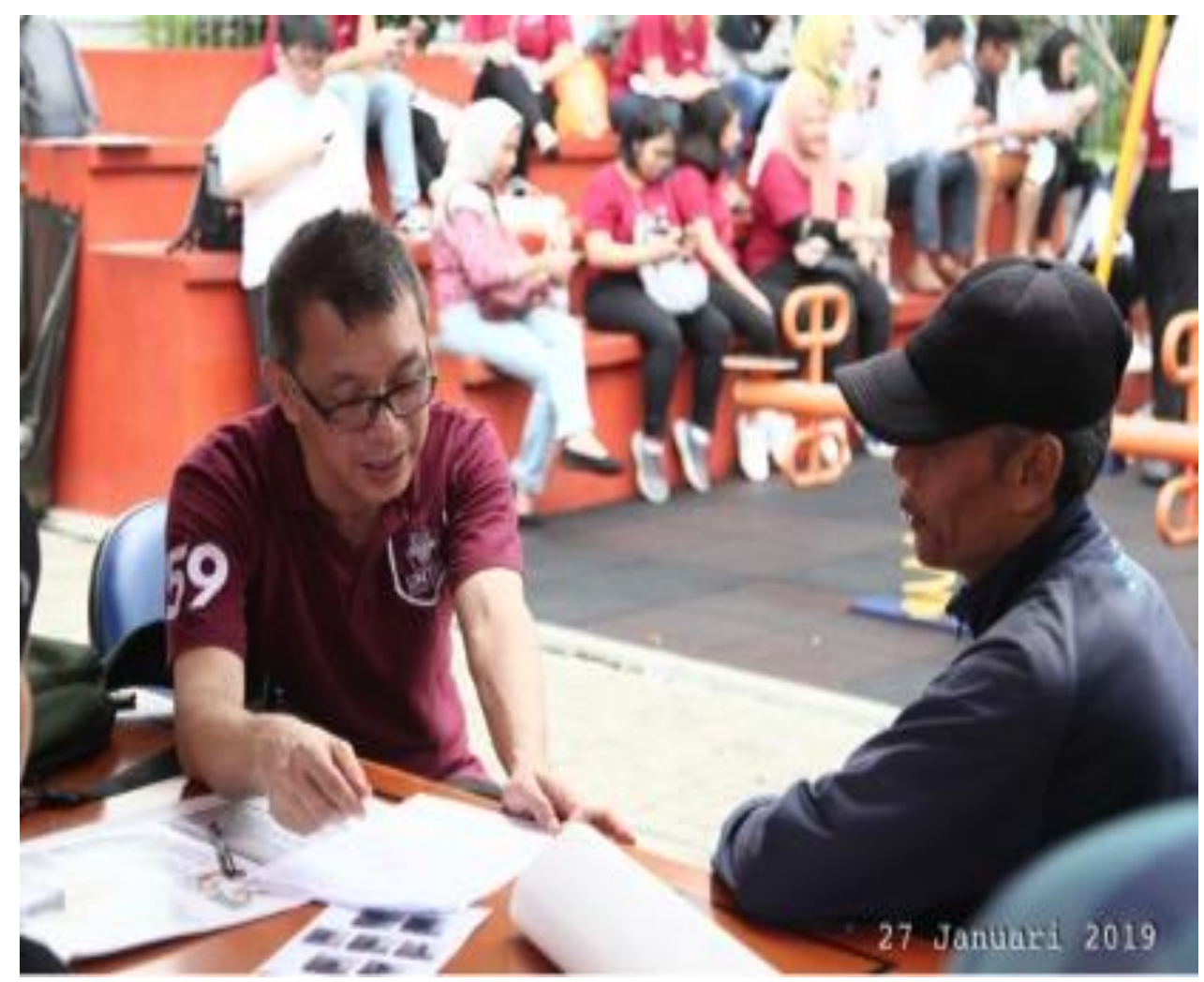

Gambar 5. Dokumentasi Kegiatan (4)

Dari delapan puluh tiga warga, didapatkan hanya 10,8\% warga yang tekanan darahnya tinggi (hipertensi), gula darah sewaktu (GDS) tinggi (>200 mg/dL) 4,8\%, kolesterol tinggi (>200 mg/dL) $16,9 \%$, dan asam urat tinggi (laki-laki $>7 \mathrm{mg} / \mathrm{dL}$; perempuan $>6 \mathrm{mg} / \mathrm{dL}$ ) $25,3 \%$. Dibandingkan dengan hasil Riskesdas 2018, prevalensi Hipertensi berdasarkan pengukuran di Kelurahan Tomang didapatkan lebih rendah. Sedangkan untuk prevalensi DM, prevalensi di Kelurahan Tomang didapatkan lebih tinggi dibandingkan dengan hasil Riskesdas.(Kementerian Badan Penelitian dan Pengembangan Kesehatan, 2018) Pada kegiatan pengabdian ini tidak dilakukan pendataan terhadap asupan makanan dan pola makan dari peserta. Berdasarkan hal tersebut, perlu dilakukan suatu penelitian untuk mengetahui faktor-faktor resiko tingginya prevalensinya DM di kelurahan Tomang.

Berdasarkan perhitungan Indeks Massa Tubuh (IMT), didapatkan lebih dari enampuluh persen warga memiliki status gizi lebih hingga gemuk. Dibandingkan dengan Riskesdas 2018, prevalensi di Kelurahan Tomang lebih tinggi.(Kementerian Badan Penelitian dan Pengembangan Kesehatan, 2018) Indeks massa tubuh (IMT) merupakan pengukuran antropometri yang paling sering digunakan untuk mengklasifikasikan status gizi pada orang dewasa, tapi tidak dapat membedakan peningkatan berat badan yang disebabkan oleh peningkatan massa otot atau massa lemak.(CDC, 2007) Pada kegiatan PKM ini tidak dilakukan pengumpulan data terhadap faktor-faktor penyebab terhadap gizi lebih dan obesitas, sehingga perlu dilakukan penelitian lanjutan untuk mengetahui hal tersebut. Karakteristik warga dapat dilihat pada Tabel 1. 
Tabel 1. Karakteristik Warga

\begin{tabular}{|c|c|c|c|}
\hline No & Karakteristik & $\mathbf{N}=\mathbf{8 3}$ & $\%$ \\
\hline \multirow[t]{3}{*}{1.} & Jenis Kelamin & & \\
\hline & Laki-laki & 14 & $16,9 \%$ \\
\hline & Perempuan & 68 & $81,9 \%$ \\
\hline \multirow[t]{7}{*}{2.} & Usia (tahun) & & \\
\hline & $<20$ & 2 & $2,4 \%$ \\
\hline & $21-30$ & 4 & $4,8 \%$ \\
\hline & $31-40$ & 12 & $14,5 \%$ \\
\hline & $41-50$ & 21 & $25,3 \%$ \\
\hline & $51-60$ & 21 & $25,3 \%$ \\
\hline & $>60$ & 23 & $27,7 \%$ \\
\hline \multirow[t]{6}{*}{3.} & Jumlah Anak & & \\
\hline & Tidak ada anak & 4 & $4,8 \%$ \\
\hline & 1 orang anak & 8 & $9,6 \%$ \\
\hline & 2 orang anak & 12 & $14,5 \%$ \\
\hline & $>2$ orang anak & 37 & $44,6 \%$ \\
\hline & Tidak menjawab & 22 & $26,5 \%$ \\
\hline \multirow[t]{6}{*}{4.} & Tingkat Pendidikan & & \\
\hline & $\mathrm{SD}$ & 21 & $25,3 \%$ \\
\hline & SMP & 13 & $15,7 \%$ \\
\hline & SMA & 20 & $24,1 \%$ \\
\hline & Perguruan Tinggi & 4 & $4,8 \%$ \\
\hline & Tidak menjawab & 25 & $30,1 \%$ \\
\hline \multirow[t]{4}{*}{5.} & Tekanan Darah & & \\
\hline & Normal & 55 & $66,3 \%$ \\
\hline & Hipertensi & 9 & $10,8 \%$ \\
\hline & Tidak Diukur & 19 & $22,9 \%$ \\
\hline \multirow[t]{3}{*}{6.} & Gula Darah Sewaktu (GDS) & & \\
\hline & Normal & 79 & $95,2 \%$ \\
\hline & Tinggi & 4 & $4,8 \%$ \\
\hline \multirow[t]{3}{*}{7.} & Kolesterol & & \\
\hline & Normal & 69 & $83,1 \%$ \\
\hline & Tinggi & 14 & $16,9 \%$ \\
\hline \multirow[t]{4}{*}{8.} & Asam urat & & \\
\hline & Normal & 41 & $49,4 \%$ \\
\hline & Tinggi & 21 & $25,3 \%$ \\
\hline & Tidak Diukur & 21 & $25,3 \%$ \\
\hline \multirow[t]{7}{*}{9.} & Status Gizi & & \\
\hline & Kurang & 1 & $1,2 \%$ \\
\hline & Normal & 14 & $16,9 \%$ \\
\hline & Kelebihan BB & 11 & $13,3 \%$ \\
\hline & Obese derajat 1 & 20 & $24,1 \%$ \\
\hline & Obese derajat 2 & 21 & $25,3 \%$ \\
\hline & Tidak diukur & 16 & $19,3 \%$ \\
\hline
\end{tabular}




\section{LUARAN YANG DICAPAI}

Pelaksanaan kegiatan pengabdian berjalan sesuai dengan perencanaan, dan berjalan lancar dan tertib. Target peserta pada pengabdian ini tidak tercapai dikarenakan pada saat pengabdian sebagian wilayah kelurahan baru mengalami musibah kebakaran.

\section{KESIMPULAN}

Kegiatan pengabdian kepada masyarakat dengan topik "Pemeriksaan Antropometri, Gula Darah, Lipid dan Asam Urat Sebagai Upaya Preventif Terhadap Penyakit Tidak Menular Di Kelurahan Tomang" dilaksanakan dengan baik dan lancar pada tanggal 27 Januari 2019, dan dihadiri oleh 83 warga kelurahan Tomang Jakarta Barat. Pada kegiatan pengabdian ini didapatkan $10,8 \%$ warga menderita hipertensi, 4,8\% dengan nilai gula darah sewaktu di atas $200 \mathrm{mg} / \mathrm{dL}, 16,9 \%$ dengan nilai kolesterol di atas $200 \mathrm{mg} / \mathrm{dL}, 25,3 \%$ dengan kadar asam urat tinggi (laki-laki >7 mg/dL; perempuan $>6 \mathrm{mg} / \mathrm{dL}$ ). Didapatkan juga $62,7 \%$ warga dengan kelebihan berat badan hingga obesitas.

\section{REFERENSI}

Alwan, A., \& MacLean, D. R. (2009). A review of non-communicable disease in low- and middle-income countries. International Health, 1(1), 3-9. https://doi.org/10.1016/j.inhe.2009.02.003

Badan Penelitian dan Pengembangan Kesehatan Kementerian Kesehatan RI. (2013). RISET KESEHATAN DASAR RISKESDAS 2013. Jakarta. Retrieved from http://www.depkes.go.id/resources/download/general/Hasil Riskesdas 2013.pdf

Bickley, L. S., \& Szilagyi, P. G. (2007). Bates' Guide to Physical Examination and History Taking (9th ed.). Lippincott Williams \& Wilkins.

CDC. (2007). Anthropometry Procedures Manual. Retrieved from https://www.cdc.gov/nchs/data/nhanes/nhanes_07_08/manual_an.pdf

Gibson, R. S. (2005). Principles of nutritional assessment. Oxford University Press.

Gowshall, M., \& Taylor-Robinson, S. D. (2018). The increasing prevalence of noncommunicable diseases in low-middle income countries: The view from Malawi. International Journal of General Medicine, 11, 255-264. https://doi.org/10.2147/IJGM.S157987 LK http://link.kib.ki.se/?sid=EMBASE\&issn=11787074\&id=doi:10.2147\%2FIJGM.S157987\& atitle $=$ The+increasing + prevalence + of + non-communicable + diseases + in + lowmiddle+income+countries $\% 3 \mathrm{~A}+$ The+view+from+Malawi\&stitle=Int.+J.+Gen.+Med.\&title $=$ International + Journal + of + General + Medicine $\&$ volume $=11 \&$ issue $=\&$ spage $=255 \&$ epage $=2$ $64 \&$ aulast=Gowshall\&aufirst=Matthew\&auinit=M.\&aufull=Gowshall+M.\&coden=\&isbn= \&pages $=255-264 \&$ date $=2018 \&$ auinit $1=$ M\&auinitm $=$

Kementerian Badan Penelitian dan Pengembangan Kesehatan. (2018). HASIL UTAMA RISKESDAS 2018 Kesehatan, 20-21.

WHO. (2014). Non communicable Diseases Country Profiles. World Health Organization, 1210. https://doi.org/10.1111/jgs.12171

World Health Organization. (n.d.). GLOBAL STATUS REPORT on noncommunicable diseases 2014.

http://apps.who.int/iris/bitstream/handle/10665/148114/9789241564854_eng.pdf?sequence=1 